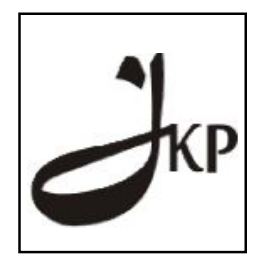

Jurnal Konseling dan Pendidikan

ISSN Cetak: 2337-6740 - ISSN Online: 2337-6880

http://jurnal.konselingindonesia.com

Volume 2 Nomor 2, Juni 2014, HIm 14-18

Info Artikel:

Diterima 04/06/2014

Direvisi 12/06/2014

Dipublikasikan 30/06/2014

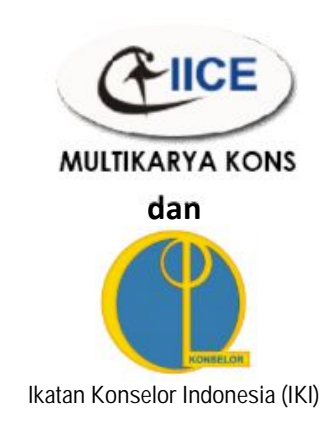

\title{
Hubungan Self-Esteem dengan Motivasi Belajar Remaja Panti Asuhan 'Aisyiyah Daerah Cabang Lubuk Bagalung Padang
}

Hermivia Olva, Yulidar Ibrahim \& Marjohan

Universitas Negeri Padang

\begin{abstract}
The teenager who have more motivation in studying will do many activities that be useful in learning process. If they are able to think and make sure about their will have more motivation to study, have a good socialization and can manage their passion. The purpose of the research is analyzing about correlation between self-esteem with motivation in studying of teenage orphanage 'Aisyiyah Lubuk Bagalung Padang. Kind of research is quantitative by using correlation descriptive. The subjects of the research are 30 students. The instruments are inventory and questionnaires. The result of the research shows that there are correlation between self-esteem and motivation in studying significantly by lowing correlation.
\end{abstract}

Keyword: Self-esteem, Learning Motivation

Copyright (C) 2014 IICE - Multikarya Kons (Padang - Indonesia) dan IKI - Ikatan Konselor Indonesia - All

Rights Reserved

Indonesian Institute for Counseling and Education (IICE) Multikarya Kons

\section{PENDAHULUAN}

Belajar bukan hanya proses dalam mengingat apa yang terlihat namun dalam proses belajar seseorang harus mampu mengalami serta merasakan apa yang dibelajarkan. Menurut Dalyono (1997:49) "belajar dapat didefenisikan suatu usaha atau kegiatan yang bertujuan mengadakan perubahan didalam diri seseorang, mencakup perubahan tingkah laku, sikap, kebiasaan, ilmu pengetahuan, keterampilan, dan sebagainya". Berbagai tuntutan dan usaha yang harus dilakukan dalam proses perubahan berbagai aspek tersebut. Salah satu aspek yang berperan penting dalam proses belajar adalah adanya motivasi. Motivasi merupakan dorongan yang timbul dalam diri individu untuk melakukan sesuatu hal demi mencapai tujuan. Menurut Sumadi Suryabrata (dalam Djaali, 2008:101) motivasi adalah "keadaan yang terdapat dalam diri seseorang yang mendorongnya untuk melakukan aktivitas tertentu guna pencapaian tujuan tertentu”. Sedangkan menurut Sardiman (2007:83) ciri-ciri motivasi sebagai berikut (a) Tekun menghadapi tugas (dapat bekerja terus-menerus dalam waktu yang lama dan tidak akan berhenti sebelum selesai) (b) Ulet dalam menghadapi kesulitan. Siswa tidak mudah putus asa, tidak memerlukan dorongan dari luar untuk berpartisipasi sebaik mungkin dan tidak cepat puas dengan prestasi yang telah dicapai, (c) menunjukkan minat terhadap bermacam-macam masalah untuk orang dewasa, Misalnya masalah pembangunan, masalah agama, politik, ekonomi, keadilan, pemberantasan korupsi, penentangan terhadap setiap tindakan kriminal, amoral, dan sebagainya (d) Lebih senang bekerja mandiri. Cepat bosan pada tugas-tugas yan rutin (hal-hal yang bersifat mekanis, berulang-ulang begitu saja, sehingga kurang kreatif (e) Dapat mempertahankan pendapatnya (kalau sudah yakin sesuatu) (f) Tidak mudah melepaskan hal yang diyakini tersebut (g) Senang mencari dan memecahkan soal-soal.

Ramaja dengan motivasi belajar tinggi akan melakukan aktifitas belajar yang bermanfaat untuk proses belajar. Senada dengan Dalyono (2010:57) "seseorang yang belajar dengan motivasi kuat, akan melaksanakan 
semua kegitan belajarnya dengan sungguh-sungguh, penuh gairah atau semangat. Sebaliknya, belajar dengan motivasi yang lemah, akan malas bahkan tidak mau mengerjakan tugas-tugas yang berhubungan dengan pelajaran.

Keyakinan tidak mampu atau tidak mempunyai kemampuan dalam mengerjakan tugas belajar dan ketidakmampuan dalam proses pembelajaran akan berakibat pada ketidakberdayaan remaja dan berkurangnya penghargaan terhadap dirinya. Berkurangnya penghargaan terhadap diri ini akan menimbulkan self-esteem yang rendah pada diri remaja. Menurut Branden (1994:208) "self-esteem merupakan keyakinan tentang kemampuan dalam mengatasi segala tantangan hidup, maka tidak ada satupun yang lebih penting selain belajar dan bagaimana mempergunakan pikiran".

Remaja yang mempunyai keyakinan yang kuat terhadap kemampuannya, maka remaja akan termotivasi untuk belajar dan akan menghadapi kesulitan belajar dengan berbagai cara dan menganggap kesulitan belajar tersebut sebagai tantangan yang harus diatasi. Harris Clemes dan Reynold Bean (2001:8) yang menyatakan bahwa "salah satu faktor terpenting yang menentukan sukses disekolah adalah harga diri. Anak-anak yang sangat cerdas namun harga dirinya rendah dan bisa mendapatkan hasil yang buruk di sekolah. Anak dengan harga diri rendah cenderung mendapat sedikit kepuasan disekolah, mereka dengan mudah kehilangan motivasi dan minat untuk belajar".

Jika remaja mampu menilai dan meyakini potensi yang dimilikinya dalam belajar, maka remaja akan menunjukkan motivasi belajar yang tinggi, mampu menjalin hubungan sosial dengan baik dan mampu mengontrol emosi dengan baik pula, begitu pula sebaliknya.

Berdasarkan hasil observasi, wawancara dan diskusi kelompok yang peneliti lakukan terhadap remaja panti asuhan diperoleh keterangan bahwa sebagian remaja panti asuhan memiliki sifat yang pemalu dan tidak berani dalam bertanya dalam diskusi, remaja kurang memperhatikan guru menerangkan materi layanan, remaja banyak berbicara dengan temannya, remaja tidak mau mencatat materi layanan yang diberikan oleh guru. berdasarkan fenomena di atas diduga remaja panti asuhan memiliki motivasi rendah.

Selain itu sebagian remaja kurang mampu bersosialisasi. Sebagian besar remaja panti asuhan kurang mampu mengontrol emosi ketika berbicara dan bercanda dengan sesama teman maupun dengan pengasuh, sehingga sering terjadi pertengkaran dan kamarahan serta kesedihan. Sebagian remaja menganggap menjadi pribadi yang kurang menarik di mata orang lain. Remaja beranggapan tidak memiliki banyak teman sekolah yang berada diluar panti yang bisa diajak untuk belajar bersama, sebagian remaja panti merasa kehidupannya kurang bahagia dari temantemannya yang tinggal dengan orang tua.

Hasil dari observasi dan wawancara tersebut didukung oleh hasil AUM UMUM Format SLTA yang telah diberikan pada remaja panti asuhan 'Aisyiyah Padang tanggal 17 Februari 2013 terungkap bahwa rata-rata 34\% masalah-masalah yang dialami oleh remaja adalah dalam bidang DPI (Diri Pribadi). Dari 27 remaja yang mengisi AUM UMUM, 18 remaja merasa bermasalah pada item 123 (rendah diri dan kurang percaya diri). Selain itu ratarata $40 \%$ remaja panti asuhan 'Aisyiyah bermasalah dalam bidang Pendidikan dan Pelajaran, dimana rata-rata masing-masing remaja memiliki 17 item yang bermasalah dalam bidang Pendidikan dan Pelajaran. Hal ini diduga remaja panti asuhan miliki self-esteem yang rendah.

\section{METODOLOGI}

Penelitian ini menggunakan metode kuantitatif dengan pendekatan analisis deskriptif korelasional. Subjek penelitian ini adalah 30 orang remaja panti asuhan. Alat yang digunakan untuk pengumpulan data dalam penelitian ini adalah inventori dan angket. Angket ini bertujuan untuk memperoleh data tentang motivasi belajar yang berjumlah 40 pernyataan Sedangkan inventori bertujuan untuk melihat self-esteem yang berjumlah 40 pertanyaan. Untuk kemungkinan jawaban inventori self-esteem menggunakan pilihan jawaban yaitu YA dan TIDAK. Jika jawaban responden YA maka skor 1 dan jika jawaban responden TIDAK maka skor $0(+)$ sebaliknya jika jawaban responden TIDAK mendapat skor 1 dan jawaban YA mendapat skor 0 (-). Sedangkan untuk setiap kemungkinan jawaban angket penelitian tentang motivasi belajar menggunakan kriteria kemungkinan pilihan jawaban yaitu: Selalu (Sl) jika tingkat kesesuaiannya 81-100\%, Sering (Sr) jika tingkat kesesuaiannya 61-80\%, Kadang-kadang (Kd) jika tingkat kesesuaiannya 41-60\%, Jarang (Jr) jika tingkat kesesuaiannya 21-40\%, dan Tidak Pernah (Tp) jika tingkat kesesuaiannya 0-20\% Untuk melihat tingkat hubungan antar kedua variabel, peneliti menggunakan rumus Correlation Product Moment dengan menggunakan program SPSS versi 16.0

\section{HASIL}


Berdasarkan hasil pengolahan data, maka hasil penelitian ini dapat digambarkan sebagai berikut:

Tabel 1. Hasil Gambaran Self-Esteem dan Motivasi Belajar

\begin{tabular}{|c|c|c|c|c|c|c|c|}
\hline \multicolumn{4}{|c|}{ Self esteem } & \multicolumn{4}{|c|}{ Motivasi belajar } \\
\hline KT & Skor & f & $\%$ & KT & Skor & f & $\%$ \\
\hline ST) & $>29$ & 5 & 16,7 & (ST) & $>179$ & 1 & 3,3 \\
\hline (T) & $24-28$ & 5 & 16,7 & (T) & $152-178$ & 10 & 33,3 \\
\hline (S) & $19-23$ & 8 & 26,7 & ( S) & $126-151$ & 11 & 36,7 \\
\hline (R) & $13-18$ & 12 & 40 & (R) & $99-125$ & 5 & 6,7 \\
\hline (SR) & $k 12$ & - & - & (SR) & $\leq 98$ & 3 & 10 \\
\hline & TOTAL & 30 & 100 & & & 30 & 100 \\
\hline
\end{tabular}

Berdasarkan tabel di atas dapat disimpulkan bahwa dari 30 orang remaja Panti Asuhan 'Aisyiyah Daerah Kota Padang, 12 orang remaja panti asuhan memiliki self-esteem rendah (40\%). Sedangkan pada motivasi belajar, 10 orang remaja panti asuhan $(33,3 \%)$ memiliki motivasi belajar tinggi dan 11 orang $(36,7 \%)$ memiliki selfesteem yang sedang.

Tabel 2. Hasil Pengolahan Data Tentang Hubungan Self-Esteem dengan Motivasi Belajar

\begin{tabular}{|l|l|r|r|l|}
\hline \multicolumn{2}{|c|}{} & $\begin{array}{l}\text { Motivasi } \\
\text { Belajar }\end{array}$ & $\begin{array}{l}\text { Self- } \\
\text { esteem }\end{array}$ & $\begin{array}{l}\text { Tingkat } \\
\text { keeratan }\end{array}$ \\
\hline $\begin{array}{l}\text { Motivasi } \\
\text { belajar }\end{array}$ & $\begin{array}{l}\text { Pearson } \\
\text { Correlation }\end{array}$ & 1 & .304 & \\
\cline { 2 - 4 } & Sig. (2-tailed) & & .103 & \multirow{2}{*}{ Rendah } \\
\cline { 2 - 4 } & $\mathrm{N}$ & 30 & 30 & \\
\hline $\begin{array}{l}\text { Self- } \\
\text { esteem }\end{array}$ & $\begin{array}{l}\text { Pearson } \\
\text { Correlation }\end{array}$ & .304 & 1 & \\
\cline { 2 - 4 } & Sig. (2-tailed) & .103 & & \\
\cline { 2 - 4 } & $\mathrm{N}$ & 30 & 30 & \\
\hline
\end{tabular}

Berdasarkan perhitungan dengan menggunakan teknik analisis pearson product moment, dapat disimpulkan bahwa Ho yang menyatakan tidak terdapat hubungan antara self-esteem dengan motivasi belajar diterima. Besarnya koefisien korelasi adalah sebesar 0.304. Dengan demikian tingkat hubungan antara self-esteem dengan motivasi belajar berada pada kategori rendah.

\section{PEMBAHASAN}

\section{Self-Esteem}

Hasil temuan penelitian self-esteem remaja panti asuhan secara keseluruhan menunjukkan bahwa remaja panti asuhan cenderung memiliki self-esteem rendah yakni sebesar $40 \%$ yakni 12 orang remaja panti asuhan memilik self-esteem yang rendah. Rendahnya self-esteem remaja panti asuhan 'Aisyiyah Daerah Kota Padang perlu mendapat perhatian dari konselor dan pengurus panti asuhan. Remaja yang memiliki self-esteem rendah 
akan merasa dirinya tidak berharga, tidak mampu, merasa tidak diperhatian dan merasa menjadi orang yang gagal serta memiliki kepercayaan diri yang buruk. Menurut Harris Clemes dan Reynold Bean (2001:8) self-esteem yang rendah akan tercermin dari prilaku. Jika pola karakteristik harga diri yang rendah terus berkembang, hal itu akan menjadi sebuah kebiasaan yang sukar dihilangkan. Selain itu menurut Branden (2011:9) "dengan penghargaan diri lebih tinggi, sikap seseorang cenderung lebih terbuka, jujur dan menjalin komunikasi yang menyenangkan sebab kita memercayai nilai pikiran di dalam hati. Sebaliknya seseorang dengan penghargaan diri rendah cenderung mengelak tanggung jawab, gagal menjalin interaksi yang komunikatif”.

\section{Motivasi Belajar}

Hasil temuan penelitian motivasi belajar remaja panti asuhan 'Aisyiyah Daerah Kota Padang secara keseluruhan menunjukkan bahwa remaja cenderung memiliki tingkat motivasi yang tinggi yakni sebesar 36,6\%. Hal ini berarti Hal ini berarti remaja panti asuhan memiliki motivasi yang tinggi dalam belajar baik itu dalam hal ketekunanan dalam belajar, ketekunan dalam menghadapi tugas, ulet dalam menghadapi kesulitan belajar, mandiri, mampu mempertahankan pendapat dan senang memecahkan dan mencari soal-soal. Hasil penelitian ini didukung oleh pendapat Dalyono (2010:57) "seseorang yang belajar dengan motivasi kuat, akan melaksanakan semua kegitan belajarnya dengan sungguh-sungguh, penuh gairah atau semangat. Sebaliknya, belajar dengan motivasi yang lemah, akan malas bahkan tidak mau mengerjakan tugas-tugas yang berhubungan dengan pelajaran.

\section{Hubungan Self-Esteem dengan Motivasi Belajar}

Berdasarkan tabel 2 dapat disimpulkan bahwa tidak terdapat hubungan antara self-esteem dengan motivasi belajar remaja panti asuhan 'Aisyiyah Daerah Kota Padang. Besarnya koefisien korelasi adalah sebesar 0.304. yang menunjukkan tingkat keeratan hubungan antara self-esteem dengan motivasi belajar berada pada kategori rendah.

Rendahnya tingkat korelasi antara self-esteem dengan motivasi belajar perlu menjadi perhatian baik bagi pengurus panti asuhan 'Aisyiyah Daerah Kota Padang maupun konselor. Karena sesuai yang dikemukakan oleh Harris Clemes dan Reynold Bean (2001:8) yang menyatakan bahwa "salah satu faktor terpenting yang menentukan sukses disekolah adalah harga diri. Anak-anak yang sangat cerdas namun harga dirinya rendah dan bisa mendapatkan hasil yang buruk di sekolah. Anak dengan harga diri rendah cenderung mendapat sedikit kepuasan disekolah, mereka dengan mudah kehilangan motivasi dan minat untuk belajar". Jadi remaja yang memiliki self-esteem yang rendah akan menunjukkan motivasi untuk belajar rendah dan tidak akan sukses dalam belajar.

Sedangkan menurut Walgito dalam Isti Ilma Patriani (2006:17) "bagi remaja yang tinggal di panti asuhan, memiliki kepercayaan diri tidak lah mudah dibandingkan dengan remaja yang tinggal diluar panti asuhan. Hal ini disebabkan karena kepercayaan diri terbentuk dalam interaksi dengan lingkungannya khususnya lingkungan sosial. Remaja panti asuhan tidak dapat menemukan lingkungan pengganti keluarga yang benar-benar dapat menggantikan fungsi keluarga. Kondisi seperti ini dapat menyebabkan terbentuknya perilaku yang inferior, pasif, menarik diri, mudah putus asa, penuh dengan ketakutan dan kecemasan".

Berdasarkan pendapat di atas dapat disimpulkan bahwa remaja yang tinggal di panti asuhan "Aisyiyah Daerah Kota Padang mendapat kesulitan dalam hal menyesuaikan diri dengan lingkungan baru dan lingkungan tersebut tidak mampu menggantikan situasi pada lingkungan keluarga sebelumnya. Hal ini sesuai dengan data yang peneliti temukan di panti asuhan 'Aisyiyah Daerah Kota Padang yang baru didirikan pada tanggal 15 Januari 2010. Panti asuhan ini baru didirikan, sehingga anak asuh yang berada dipanti masih mengalami masa orientasi baik dari segi lingkungan tempat tinggal, lingkungan sosial, dan status sosial serta aturan-aturan yang baru.

Selain itu, menurut Yusuf (dalam Aat Sriati, 2002) faktor-faktor yang melatar belakangi self-esteem adalah (a) Pengalaman, merupakan suatu bentuk emosi, perasaan, tindakan, dan kejadian yang pernah dialami individu yang dirasakan bermakna dan meninggalkan kesan dalam hidup individu (b) Pola asuh, merupakan sikap orangtua dalam berinteraksi dengan anak-anaknya yang meliputi cara orangtua memberikan aturan-aturan, hadiah, hukuman, cara orangtua menunjukkan otoritasnya, dan cara orangtua memberikan perhatiannya serta tanggapan terhadap anaknya (c) Lingkungan, memberikan dampak besar kepada remaja melalui hubungan yang baik antara remaja dengan orangtua, teman sebaya, dan lingkungan sekitar sehingga menumbuhkan rasa nyaman dalam penerimaan sosial dan harga dirinya (d) Sosial ekonomi, merupakan sesuatu yang mendasari perbuatan seseorang 
untuk memenuhi dorongan sosial yang memerlukan dukungan finansial yang berpengaruh pada kebutuhan hidup sehari-hari.

\section{PENUTUP}

Berdasarkan hasil analisis data yang telah dibahas maka dapat diambil kesimpulan bahwa terdapat hubungan yang signifikan antara self-esteem dengan motivasi belajar remaja panti asuhan 'Aisyiyah Daerah Kota Padang dengan tingkat keeratan hubungan rendah dan tingkat koefisien korelasi adalah 0.304

Berkenaan dengan temuan penelitian, penulis mengemukakan beberapa saran yaitu: Pertama, Bagi remaja penghuni panti asuhan diharapkan harus mampu mempertahankan dan meningkatkan motivasi belajar dengan cara tetap tekun dalam belajar, tekun dalam menghadapi tugas, dan ulet dalam menghadapi kesulitan belajar. Selain itu remaja panti asuhan 'Aisyiyah Daerah Kota Padang dapat meningkatkan self-esteem dengan cara tetap belajar memahami diri sendiri, memiliki tujuan hidup yang jelas, belajar bertanggung jawab terhadap tugas yang diberikan, selalu berfikir positif, tetap optimis dan mandiri.

Kedua bagi pengasuh di panti asuhan hendaknya dapat membantu remaja dalam meningkatkan self-esteem dengan cara memperlakukan remaja panti asuhan ini sama dengan remaja yang lain seperti pemberian tugas secara adil, memberikan pujian dan penghargaan terhadap keberhasilan yang dicapai oleh para remaja panti asuhan. Hal ini akan membuat remaja merasa diterima, merasa mampu, merasa dibutuhkan dan merasa dihormati. . Sehingga dapat meningkatkan motivasi remaja dalam belajar.

Ketiga bagi peneliti yang berminat untuk mengadakan penelitian lanjutan disarankan untuk menindaklanjuti penelitian ini dengan melihat perbandingan self-esteem antara remaja panti asuhan dengan remaja yang tinggal dengan orang tua. Selain itu peneliti selanjutnya diharapkan untuk memperluas penelitian ini dari segi lain yang relevan

\section{DAFTAR PUSTAKA}

Aat Sriati. 2002. Harga diri. www.belajar psikologi.com. Diakses pada tanggal 9 Maret 2013.

Dalyono. 1997. Psikologi Pendidikan. Jakarta: Rineka Cipta.

Dalyono. 2010. Psikologi Pendidikan. Jakarta: Rineka Cipta.

Djali. 2007. Psikologi Pendidikan. Jakarta: Bumi Aksara

Harris Clemes dan Reynold Bean (Alih Bahasa Anton Adiwiyoto). 2001. Seri Membentuk Anak Seutuhnya. Membangkitkan Harga Diri Anak. Jakarta: Mitra Utama

Isti Ilma Patriani. 2006. Kepercayaan Diri pada Remaja Penghuni Panti Asuhan ditinjau dari Harga Diri (Jurnal Skripsi Online). Semarang: Unversitas Katolik Soegijapranata

Sardiman. 2007. Interaksi dan motivasi belajar mengajar. Jakarta : PT. Raja Grafindo Persada. 